\title{
COMPLIANCE EVOLUTION TOWARD THE IIRF IN THE CASE OF EUROPEAN FINANGIAL INSTITUTION: PUBLIC VS. PRIVATE ORGANIZATION
}

\author{
Gianluca ZANELLATO ${ }^{\text {a* }}$ \\ a) Babes-Bolyai University, Faculty of Economic Science and Business \\ Administration, Cluj-Napoca
}

Please cite this article as:

Article History:

Zanellato, G., 2021. Compliance evolution toward Received: 10 September 2021 the IIRF in the case of European financial institution: Accepted: 28 September 2021 public vs. private organization. Review of Economic Studies and Research Virgil Madgearu, 14(2), pp.105-137. doi: 10.24193/RVM.2021.14.82.

Abstract: Financial organizations are playing an essential role in our societies.
The economic crises brought a loss of confidence by citizens, had repercussions in
government budgets as aid was provided to save financial organizations. Today
after ten years of unfortunate events, stakeholders are more interested in the
activity of similar organizations than ever. The increasing need for information
brought financial organizations to adopt different non-financial reports to
communicate their activity toward their stakeholders, including the latest trend in
corporate reporting: "Integrated Report." Therefore, the present paper analyses the
compliance evolution toward the International Integrated Reporting Framework
and contraposes the results in the context of the public-owned institution and
private-owned institutions. The results of the study outline an increasing compliance
toward the framework and it demonstrates State Owned Enterprises predilection
toward content that help them in explaining their existing reasons. Key words: integrated reporting; financial institutions; public sector; private sector; content analysis

JEL Classification: $H_{70}$; M1O; M14; M2O; M4O; QO1

(C) 2021 Alma Mater Publishing House. All rights reserved.

* Corresponding author. E-mail address: gianluca.zanellato@econ.ubbcluj.ro. 
Review of Economic Studies and Research Virgil Madgearu, 2021, 14(2)

\section{References:}

1. Abeysekera, I., 2013. A template for integrated reporting. Journal of Intellectual Capital, 14(2), pp.227-245.

2. Acharya, V.V., and Richardson, M.P. eds. (2009). Restoring financial stability: how to repair a failed system. New Jersey: John Wiley and Sons.

3. Adams, S., and Simnett, R., 2011. Integrated Reporting: An opportunity for Australia's not for profit sector. Australian Accounting Review, 21(3), pp.292-301. https://doi.org/ 10.1111/j.1835-2561.2011.00143.x.

4. Araya, H.M.B., Mas, E.S., and Garrido, F.P., 2014. Sustainability reporting in European cooperative banks: An exploratory analysis. REVESCO, Revista de Estudios Cooperativos, 115, pp.30-56. https://doi.org/10.5209/rev_REVE.2014.v115.45277.

5. Argento, D., Culasso, F., and Truant, E., 2018. From Sustainability to Integrated Reporting: The Legitimizing Role of the CSR Manager. Organization and Environment, 32(4). https://doi. org/10.1177/1086026618769487.

6. Bartocci L., Picciaia F. (2013) Towards Integrated Reporting in the Public Sector, pp.191-204. In: Busco C., Frigo M., Riccaboni A., Quattrone P. (eds.) Integrated Reporting. Springer, Cham. https:// doi.org/10.1007/978-3-319-02168-3_12.

7. Bruton, G.D., Peng, M.W., Ahlstrom, D., Stan, C., and Xu, K., 2015. State-owned enterprises around the world as hybrid organizations. The Academy of Management Perspectives, 29(1), pp.92-114. https://doi.org/10.5465/amp.2013.0069.

8. Buys, P., and Van Niekerk, E., 2014. The South African financial services industry's integrated reporting compliance with the global reporting initiative framework. Banks and Bank Systems, 9(4), pp.107-115.

9. Castelo Branco, M., and Lima Rodrigues, L. (2006). Communication of corporate social responsibility by Portuguese banks: A legitimacy theory perspective. Corporate Communications: An International Journal, 11(3), pp.232-248. https://doi. org/10.1108/13563280610680821.

10. Cheng, M., Green, W., Conradie, P., Konishi, N., and Romi, A., 2014. The International Integrated Reporting Framework: Key Issues and 
ZaNELlato, Compliance Evolution TOWARD THE IIRF...

Future Research Opportunities. Journal of International Financial Management and Accounting, 25(1), pp.90-119. https://doi. org/10.1111/jifm.12015.

11. Christiansen, H., 2011. The Size and Composition of the SOE Sector in OECD Countries. OECD Corporate Governance Working Papers, 5 pp.80-98 [online] Available at: <https://www.oecd-ilibrary.org/ docserver $/ 5 \mathrm{~kg} 54 \mathrm{cwpsos} 3$-en.pdf?expires $=1639325100 \& \mathrm{id}=\mathrm{id} \& \mathrm{ac}$ cname $=$ guest $\&$ checksum $=29 \mathrm{C} 8380995 \mathrm{~F} 7817 \mathrm{~B} 7463030552923 \mathrm{~F}$ 6B $>$ [Accessed 1 September 2021].

12. Churet, C., and Eccles, R., 2014. Integrated Reporting, Quality of Management and Financial Performance. Journal of Applied Corporate Finance, 26(1), pp. 56-64. https://doi.org/10.1111/ jacf.12054.

13. Cormier, D., and Gordon, I.M., 2001. An examination of social and environmental reporting strategies. Accounting, Auditing and Accountability Journal, 14(5), pp.587-617. https://doi.org/10.1108/ EUMooooooooo6264.

14. de Villiers, C., Rinaldi, L., and Unerman, J., 2014. Integrated Reporting: Insights, gaps and an agenda for future research. Accounting, Auditing and Accountability Journal, 27(7), pp. 10421067. https://doi.org/10.1108/AAAJ-06-2014-1736.

15. Deegan, C., Rankin, M., and Tobin, J., 2002. An examination of the corporate social and environmental disclosures of BHP from 1983-1997: A test of legitimacy theory. Accounting, Auditing and Accountability Journal, 15(3), pp.312-343. https://doi. org/10.1108/09513570210435861.

16. del Baldo, M., 2015. Is It Time for Integrated Reporting in Small and Medium-Sized Enterprises? Reflections on an Italian Experience, CSR, Sustainability, Ethics \& Governance. In: S.O. Idowu, C.S. Frederiksen, A.Y. Mermod and M.E.J. Nielsen eds., Corporate Social Responsibility and Governance, edition 127, pp.183-209, Springer. https://doi.org/10.1007/978-3-319-10909-1_9.

17. Dumay,J.,Bernardi,C.,Guthrie,J., andDemartini,P.,2016.Integrated reporting: a structured literature review. Accounting Forum, 40(3), pp.166-185. https://doi.org/10.1016/j.accfor.2016.06.001.

18. Dumitru, M., and Guse, G.R., 2017. The Legitimacy of the International Integrated Reporting Council. Journal of Accounting and Management Information Systems, 16(1), pp.30-58. https:// doi.org/10.24818/jamis.2017.01002. 
Review of Economic Studies and Research Virgil Madgearu, 2021, 14(2)

19. Eccles, R.G., and Krzus, M.P., 2010. One report: Integrated reporting for a sustainable strategy. John Wiley and Sons.

20. Eccles, R.G., and Saltzman, D., 2011. Achieving sustainability through integrated reporting. Stanford Social Innovation Review, 9(3), pp.56-61.

21. European Commission, 2014. Directive 2014/95/EU of the European Parliament and the Council of 22 October 2014 amending Directive 2013/34/EU as Regards Disclosure of Non-Financial and Diversity Information by Certain Large Undertakings and Groups; EU Commission: Brussels, Belgium, pp. 1-9.

22. European Commission, 2017. Guidelines on Non-Financial Reporting (Methodology for Reporting Non-Financial Information) (2017/C 215/o1) [online] Available at: <www.ec.europa.eu/antitrafficking/ sites/antitrafficking/files/guidelines_on_non-financial_reporting. pdf(accessedon23January2018) $>$ [Accessed 1 September 2021].

23. Gray, R., Dillard, J., and Spence, C., 2009. Social accounting research as if the world matters: an essay in Postalgia and a new absurdism. Public Management Review, 11(5), pp.545-573. https:// doi.org/10.1080/14719030902798222.

24. Greiling, D., and Grüb, B., 2014. Sustainability reporting in Austrian and German local public enterprises. Journal of Economic Policy Reform, 17(3), pp.209-223. https://doi.org/10.1080/17487870.201 4.909315 .

25. Greiling, D., Traxler, A.A., and Stötzer, S., 2015. Sustainability reporting in the Austrian, German and Swiss public sector. International Journal of Public Sector Management, 28(4/5), pp.404-428. https://doi.org/10.1108/IJPSM-04-2015-0064.

26. Guthrie, J., Manes-Rossi, F., and Orelli, R.L., 2017. Integrated reporting and integrated thinking in Italian public sector organisations. Meditari Accountancy Research, 25(4), pp.553-573. https://doi.org/10.1108/MEDAR-06-2017-0155.

27. Guthrie, J., Petty, R., and Ricceri, F., 2006. The voluntary reporting of intellectual capital: Comparing evidence from Hong Kong and Australia. Journal of Intellectual Capital, 7(2), pp. 254-271. https:// doi.org/10.1108/14691930610661890.

28. Halachmi, A., Greiling, D., 2013. Transparency, E-Government, and Accountability. Some Issues and Considerations. Public Performance and Management Review, 36(2), pp.562-584. 
ZANELlato, COMPLIANCE EVOLUTION TOWARD THE IIRF...

29. Hughen, L., Lulseged, A., and Upton, D.R., 2014. Improving stakeholder value through sustainability and integrated reporting. The CPA Journal, 84(3), p.57.

30. Integrated Reporting. International Integrated Reporting Framework, 2013. [online] Available at: <www. integratedreporting.org/resource/ international-ir-framework/> [Accessed 23 May 2018].

31. International Integrated Reporting Comitee, IR Examples Database [online] Available at: <http://examples.integratedreporting.org/ home $>$ [Accessed 20 May 2018].

32. Jeucken, M., 2010. Sustainable finance and banking: The financial sector and the future of the planet. Routledge.

33. Katsikas, E., Rossi, F.M., and Orelli, R.L., 2016. Towards Integrated Reporting: Accounting Change in the Public Sector. Springer

34. Kılıç, M., and Kuzey, C., 2018. Assessing current company reports according to the IIRC integrated reporting framework. Meditari Accountancy Research, 26(2), pp.305-333. https://doi.org/10.1108/ MEDAR-04-2017-0138.

35. Krasodomska, J., 2015. CSR disclosures in the banking industry. Empirical evidence from Poland. Social Responsibility Journal, 11(3), pp.406-423. https://doi.org/10.1108/SRJ-02-2013-0019.

36. Krippendorff, K., 1980. Content analysis: an introduction to its methodology. Sage Publications, Inc.

37. Krzus, M., 2011. Integrated reporting: if not now, when? IRZ, 6, pp.271-276 [online] Available at: <http://www.mikekrzus.com/ resources/IRZ-Integrated-reporting.pdf $>$ [Accessed 8 May 2021].

38. Lentner, C., Szegedi, K., and Tatay, T., 2015. Corporate social responsibility in the banking sector. Public Finance Quarterly, State Audit Office of Hungary, 6o(1), pp.95-103.

39. Lindblom, C.K., 1994. The implications of organizational legitimacy for corporate social performance and disclosure. In Critical Perspectives on Accounting Conference, New York.

40. Linsley, P.M., and Shrives, P.J., 2006. Risk reporting: A study of risk disclosures in the annual reports of UK companies. The British Accounting Review, 38(4), pp.387-404.

41. Lodhia, S., 2015. Exploring the transition to integrated reporting through a practice lens: an Australian customer owned bank perspective. Journal of Business Ethics, 129(3), pp.585-598. https:// doi.org/10.1007/s10551-014-2194-8. 
42. Luke, B., 2010. Examining Accountability Dimensions In State Owned Enterprises. Financial Accountability and Management, 26, pp.134-162. https://doi.org/10.1111/j.1468-0408.2010.00496.x.

43. Manes-Rossi, F., Tiron-Tudor, A., Nicolò, G., and Zanellato, G., 2018. Ensuring More Sustainable Reporting in Europe Using NonFinancial Disclosure-De Facto and DeJure Evidence.Sustainability, 10(4), pp. 1162. https://doi.org/10.3390/su10041162.

44. Marx, B., and Mohammadali-Haji, A., 2014. Emerging trends in reporting: an analysis of integrated reporting practices by South African top 40 listed companies. Journal of Economic and Financial Sciences, 7(1), pp.231-250. https://doi.org/10.4102/jef.v7i1.138.

45. Matuszak, Ł., and Różańska, E., 2017. CSR Disclosures in Listed Banks-Current State and Future Perspective. Prace Naukowe Uniwersytetu Ekonomicznego we Wrocławiu, 478, pp.311-323.

46. Mio, C. ed., 2016. Integrated Reporting: A New Accounting Disclosure. Springer.

47. Mishra, R.K., 2014. Role of State-Owned Enterprises in India's Economic Development. [online] Available at: <https://www. oecd.org/daf/ca/workshop_soesdevelopmentprocess_india.pdf> [Accessed 20 May 2018].

48. Musacchio, A. and Flores-Macias, F., 2009. The Return of StateOwned Enterprises. Harvard International Review (website) [online] Available at: < https://www.hbs.edu/faculty/Pages/item. aspx?num $=36235>$ [Accessed 20 June 2021].

49. Neu, D., Warsame, H., and Pedwell, K., 1998. Managing public impressions: Environmental disclosures in annual reportsa. Accounting, organizations and society, 23(3), pp. 265-282. https:// doi.org/10.1016/So361-3682(97)oooo8-1.

50. Nkonki. 2015. Integrated Reporting: A New Era for Public Sector Entities in South Africa. [online] Available at: <https://www. nkonki.com/wp-content/themes/Nkonki/media/ups/nkonki-socintegrated-reporting-awards-2015.pdf $>$ [Accessed 20 May 2018].

51. OECD, 2015. OECD Guidelines on Corporate Governance of StateOwned Enterpises, 2015 Edition, OECD Publishing, Paris;

52. Oliver, C., 1991. Strategic responses to institutional processes. Academy of Management Review, 16(1), pp.145-179. https://doi. org/10.5465/amr.1991.4279002.

53. Rivera-Arrubla, Y.A., Zorio-Grima, A., and García-Benau, M.A., 2017. Integrated reports: disclosure level and explanatory factors. Social 
ZaNELlato, COMPLIANCE EVOLUTION TOWARD THE IIRF...

Responsibility Journal, 13(1), pp.155-176. https://doi.org/10.1108/ SRJ-02-2016-0033.

54. Setia, N., Abhayawansa, S., Joshi, M., and Huynh, A.V., 2015. Integrated reporting in South Africa: some initial evidence. Sustainability Accounting, Management and Policy Journal, 6(3), pp. 397-424. https://doi.org/10.1108/SAMPJ-03-2014-0018.

55. Sofian, I. and Dumitru, M., 2017. The Compliance of the Integrated Reports Issued by European Financial Companies with the International Integrated Reporting Framework. Sustainability, 9(8), pp. 1319. https://doi.org/10.3390/su9081319.

56. Surty, M.I., 2016. Trends in integrated reporting: a state owned company analysis (Doctoral dissertation).

57. Tan, J., 2005. Venturing in turbulent water: A historical perspective of economic reform and entrepreneurial transformation. Journal of Business Venturing, 20(5), pp.689-704. http://dx.doi.org/10.2139/ ssrn.1552135.

58. Tsang, E.W., 1998. A longitudinal study of corporate social reporting in Singapore: The case of the banking, food and beverages and hotel industries. Accounting, Auditing and Accountability Journal, 11(5), pp.624-635. https://doi.org/10.1108/09513579810239873.

59. Venturelli, A., Caputo, F., Cosma, S., Leopizzi, R., and Pizzi, S., 2017. Directive 2014/95/EU: Are Italian Companies Already Compliant? Sustainability, 9(8), pp.1385. https://doi.org/10.3390/su9081385.

6o. Weber, R.P., 1990. Basic content analysis. Newbury Park: SAGE Publications, Inc. https://dx.doi.org/10.4135/9781412983488.

61. Wild, S., and van Staden, C., 2013. Integrated reporting: initial analysis of early reporters-an institutional theory approach. In 7th Asia Pacific Interdisciplinary Accounting Research Conference, pp.26-28.

62. World Economic Forum, 2013. The Role of Financial Services in Society A Multi-stake holder Compact, in collaboration with Oliver Wyman [online] Available at: <http://www3.weforum.org/docs/ WEF_FS_RoleFinancialServicesSociety_Report_2013.pdf $>$.

63. Zhou, S., Simnett, R., and Green, W., 2017. Does integrated reporting matter to the capital market? Abacus, 53(1), pp.94-132. https://doi. org/10.1111/abac.12104. 